\title{
Synergistic Effects of Sulfated Polysaccharides from Mexican Seaweeds against Measles Virus
}

\author{
Karla Morán-Santibañez, ${ }^{1}$ Lucia Elizabeth Cruz-Suárez, ${ }^{2}$ Denis Ricque-Marie, ${ }^{2}$ \\ Daniel Robledo, ${ }^{3}$ Yolanda Freile-Pelegrín, ${ }^{3}$ Mario A. Peña-Hernández, ${ }^{1}$ \\ Cristina Rodríguez-Padilla, ${ }^{1}$ and Laura M. Trejo-Avila ${ }^{1}$ \\ ${ }^{1}$ Laboratorio de Inmunología y Virología, Facultad de Ciencias Biológicas, Universidad Autónoma de Nuevo León, \\ Ciudad Universitaria, CP 66455, San Nicolás de los Garza, NL, Mexico \\ ${ }^{2}$ Programa Maricultura, Facultad de Ciencias Biológicas, Universidad Autónoma de Nuevo León, \\ Ciudad Universitaria, CP 66455, San Nicolás de los Garza, NL, Mexico \\ ${ }^{3}$ Cinvestav Unidad Mérida, Km 6 Carretera Antigua a Progreso, Cordemex, AP 73, 97310 Mérida, YUC, Mexico
}

Correspondence should be addressed to Laura M. Trejo-Avila; laura.trejoav@uanl.edu.mx

Received 18 March 2016; Revised 11 May 2016; Accepted 16 May 2016

Academic Editor: Ibrahim M. Banat

Copyright (C) 2016 Karla Morán-Santibañez et al. This is an open access article distributed under the Creative Commons Attribution License, which permits unrestricted use, distribution, and reproduction in any medium, provided the original work is properly cited.

\begin{abstract}
Sulfated polysaccharides (SPs) extracted from five seaweed samples collected or cultivated in Mexico (Macrocystis pyrifera, Eisenia arborea, Pelvetia compressa, Ulva intestinalis, and Solieria filiformis) were tested in this study in order to evaluate their effect on measles virus in vitro. All polysaccharides showed antiviral activity (as measured by the reduction of syncytia formation) and low cytotoxicity (MTT assay) at inhibitory concentrations. SPs from Eisenia arborea and Solieria filiformis showed the highest antiviral activities (confirmed by qPCR) and were selected to determine their combined effect. Their synergistic effect was observed at low concentrations $(0.0274 \mu \mathrm{g} / \mathrm{mL}$ and $0.011 \mu \mathrm{g} / \mathrm{mL}$ of E. arborea and S. filiformis SPs, resp.), which exhibited by far a higher inhibitory effect (96\% syncytia reduction) in comparison to the individual SP effects $(50 \%$ inhibition with $0.275 \mu \mathrm{g} / \mathrm{mL}$ and $0.985 \mu \mathrm{g} / \mathrm{mL}$ of E. arborea and S. filiformis, resp.). Time of addition experiments and viral penetration assays suggest that best activities of these SPs occur at different stages of infection. The synergistic effect would allow reducing the treatment dose and toxicity and minimizing or delaying the induction of antiviral resistance; sulfated polysaccharides of the tested seaweed species thus appear as promising candidates for the development of natural antiviral agents.
\end{abstract}

\section{Introduction}

Latin America has an important and diverse group of seaweed species [1]. Recent data on seaweed management in this region have described the main harvest and aquaculture taking place in Argentina, Brazil, Chile, Peru, and Mexico [2]. One of the goals of seaweeds exploitation is to diversify their application by screening their diverse bioactive compounds, which remain unexplored in nutraceutical and pharmaceutical areas [3]. Different chemical compounds have been isolated from algae, including polysaccharides, which have been subjected to a variety of studies due to their extensive bioactivities and applications [4].

An increasing number of biological activities of seaweed polysaccharides have been reported in the last decades, where sulfated polysaccharides (SPs) are among the most studied compounds [5]. SPs include a complex group of macromolecules with numerous activities such as antioxidant $[6,7]$, antitumor $[8,9]$, anticoagulant $[6]$, anti-inflammatory $[6,10]$, and antiviral $[11,12]$.

Antiviral activity of SPs was first reported in 1958 [13] and over the years a substantial research has been focused on this field. SP can be obtained from each of the three main classes of seaweed: fucoidans and alginates from brown algal species, agaroids and carrageenans from red macroalgae, and ulvans from green seaweeds [14].

Fucoidans have shown a potent antiviral activity against numerous enveloped viruses including herpes simplex virus type 1 (HSV-1) [15], human immunodeficiency virus [16], 
influenza A virus [17], and different kind of paramyxoviruses such as Newcastle disease virus (NDV) and canine distemper virus (CDV) $[18,19]$. In vitro and in vivo antiretroviral effects of alginates preventing syncytium formation and reducing the P24 core antigen level have been demonstrated [20]. Antiviral activity of carrageenans has been demonstrated in vitro against human papillomavirus (HPV), acting mainly on the inhibition of HPV virions binding to cells, and also in vivo by preventing infection by different HPV genotypes [21, 22]. Recently, antiviral activity against NDV of ulvan from Ulva clathrata cultivated in Mexico has been reported [23].

Nowadays, combining multiple drugs is a primary approach for improving antiviral effects within the antiviral drug therapy field. The advantages of multidrugs combination are the reduction of individual drugs doses, a decrease in the side effects of antiviral agents, and the prevention of drugresistant viruses emergence. Drug combination theories provide an ideal tool for this purpose to understand the benefits of multidrugs combinations therapy [24].

Measles virus $(\mathrm{MeV})$ belongs to the Paramyxoviridae family of Mononegavirales, is a nonsegmented negativestrand RNA virus, and causes a highly contagious disease [25]. Although preventable by vaccination, measles still remains one of the causes of death among young children worldwide [26]. Many new antiviral drugs have been licensed in recent years, most of which are used for the treatment of HIV infections [27]. The investigation of natural antivirals isolated from marine sources is an interesting approach in the development of new antiviral agents. In the present study, we tested the antiviral activity of SPs isolated from five Mexican seaweeds against $\mathrm{MeV}$. The aim of this research was to develop new candidates of antiviral drugs that could help to control viral infection diseases.

\section{Materials and Methods}

\subsection{Antiviral Agents}

2.1.1. Collection of Seaweed. Five species of macroalgae were collected from the Mexican coasts and tested for this study: three brown seaweeds from Baja California (Macrocystis pyrifera, Eisenia arborea, and Pelvetia compressa), one green seaweed from Southern Baja California (Ulva intestinalis), and one red seaweed from Yucatan (Solieria filiformis).

Macrocystis pyrifera (Linnaeus) C. Agardh was collected in Bahía de Ensenada (Manto Jantay) in front of the Salsipuedes beach (31.983-116.815), in January 2013. Eisenia arborea J. E. Areschoug and Pelvetia compressa (J. Agardh) De Toni were collected in the Escalera Zone, North of Punta China (31.520-116.650) in December 2014-January 2015. The green alga Ulva intestinalis (Linnaeus) was collected from the water drainage channel of the Gran Mar shrimp farm, on the Baja California West coast (24.434-111.584) in August 2014.

Solieria filiformis (Kützing) P. W. Gabrielson, a red seaweed considered as a potential source of $\iota$-carrageenan [28], was obtained from an aquaculture facility at the Telchac Marine station-CINVESTAV, Yucatan (Mexico), where it is periodically cultivated in bimonthly cycles in semiopen tanks as part of an Integrated Multitrophic aquaculture system.
The sample used came from a batch cultured from April to May 2014.

Once harvested, the brown and green algae samples were washed in seawater to eliminate sand, shells, and epibionts and dried under shade, while the cultivated red algae was washed with fresh water and dried in an oven at $60^{\circ} \mathrm{C}$. Prior to extraction, the samples were cut into small $2-3 \mathrm{~cm}$ pieces and ground to pass through a $0.5 \mathrm{~mm}$ sieve (Turbomolino Pulvex 200 mill).

2.1.2. Extraction and Purification of Sulfated Polysaccharides. Polysaccharides extraction was performed after extraction of polyphenols [29]. Briefly $10 \mathrm{~g}$ of alga powder was washed with distillated water and dried at room temperature overnight.

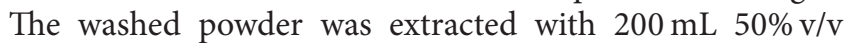
ethanol and sonicated for $30 \mathrm{~min}$ at room temperature, followed with an extraction period in a bath shaker at $70^{\circ} \mathrm{C}$ during 2 hours. The samples were centrifuged for $15 \mathrm{~min}(2500 \mathrm{rpm})$. The pellet was used for the polysaccharide extraction according to the procedure described by Tako et al. 2000 and Ale et al. 2012 [30, 31]. Briefly, $200 \mathrm{~mL}$ of $0.1 \mathrm{M} \mathrm{HCl}$ was added to the algae pellet and heated for 1 hour at boiling temperature and centrifuged at $3500 \mathrm{rpm}$ for 10 minutes. The supernatant was recovered and absolute ethanol was added $(4: 1)$ for polysaccharides precipitation. Once precipitated, the polysaccharides were separated from the aqueous medium by centrifugation at $3500 \mathrm{rpm}$ for 10 minutes; the supernatant was discarded and the pellet was washed three times with $96 \%$ ethanol to remove residual pigments and finally resuspended in a minimum amount of distilled water for a 72-hour dialysis with stirring. The dialyzed product was precipitated with absolute ethanol $(4: 1)$. Polysaccharide extracts were lyophilized and weighed to calculate their yield.

\subsubsection{Characterization of Selected Polysaccharide Extracts}

(1) FT-IR Spectra Analysis. IR spectra of aqueous extracted polysaccharides from Solieria filiformis and Eisenia arborea were obtained using diffuse reflectance infrared Fourier transform spectroscopy (DRIFTS). Scans were performed at room temperature in the infrared region between 4000 and $400 \mathrm{~cm}^{-1}$ on a Thermo Nicolet Nexus 670 FT-IR spectrometer. The infrared spectra of commercial available carrageenan ( $\iota$-carrageenan C1138, $\kappa$-carrageenan C1013), fucoidan from Fucus vesiculosus (F5631), alginic acid (A7003) from SigmaAldrich (St. Louis, MO, USA), and $\lambda$-carrageenan from Celtic Colloids Inc. (B. Blakemore) were included for comparison.

(2) NMR Spectra Analysis. ${ }^{13} \mathrm{C}-\mathrm{NMR}$ spectra were acquired on a Varian 600 spectrometer. The extracts were exchanged twice with $99.8 \%$ deuterium oxide (D2O) with intermediate lyophilization and dissolved at $10 \mathrm{mg} \mathrm{mL}^{-1}$ in D2O. Sodium [3-trimethylsilyl 2,2',3,3'-2-H4] propionate (TSP-d4) was used as an internal reference to $0.00 \mathrm{ppm}$.

(3) Carbohydrate Determination. For determination of total sugars in the samples acid hydrolysis of the extracts was performed. A solution with $25 \mathrm{mg}$ of polysaccharide extract in $100 \mathrm{~mL}$ of $1 \mathrm{M} \mathrm{H}_{2} \mathrm{SO}_{4}$ was prepared and boiled for 3 hours; 
subsequently, an aliquot of $1 \mathrm{~mL}$ of each extract was taken. Anthrone reagent $(5 \mathrm{~mL})$ was added to the aliquot, placed in a water bath for 12 minutes, and cooled down at room temperature. Absorbance was read at $630 \mathrm{~nm}$. Quantification was performed against a calibration curve of a stock solution of fucose.

(4) Sulfate Content Determination. The analysis was performed using the turbidimetric method of Jackson and McCandless, 1978 [32]. Briefly, this quantification of sulfates was determined by measuring turbidity as barium sulfate when adding $1.2 \mathrm{~mL}$ of TCA $8 \%$ and $0.6 \mathrm{~mL}$ of $0.01 \%$ reaction reagent (agarose/barium chloride) to the sample; reaction was homogenized by stirring for 35 minutes. The turbidity was determined at $500 \mathrm{~nm}$ in a Shimadzu UV-Vis spectrophotometer 1601. The calibration curve was performed with potassium sulfate $\left(\mathrm{K}_{2} \mathrm{SO}_{4}\right)$ with a concentration of 0 to $100 \mu \mathrm{g}$ of $\mathrm{SO}_{4}{ }^{-2} / \mathrm{mL}$. SP extracts of Solieria filiformis and Eisenia arborea were weighed $(7 \mathrm{mg})$, and $1 \mathrm{~mL}$ of $1 \mathrm{~N} \mathrm{HCl}$ was added and heated at $105^{\circ} \mathrm{C}$ for 12 hours in a thermoblock (Lab line). A dilution was performed with $10 \mathrm{~mL}$ of deionized water; samples were then filtered using a microfilter with Whatman paper of $1.2 \mu \mathrm{m}$ and an aliquot of $1.1 \mathrm{~mL}$ of the samples was taken for quantification. Analysis was performed by triplicate.

2.2. Cells and Virus. Vero cells were grown at $37^{\circ} \mathrm{C}$ in a $5 \% \mathrm{CO}_{2}$ atmosphere in Dulbecco's Modified Eagle Medium Nutrient Mixture F-12 (DMEM/F12, Gibco Invitrogen, USA) supplemented with $5 \%$ fetal bovine serum (FBS, Gibco Invitrogen, USA) and $1 \%$ antibiotic (Gibco Invitrogen, USA).

Measles virus (Edmonston strain) was purchased from ATCC (ATCC ${ }^{\circledR}$ VR-24 ${ }^{\mathrm{TM}}$ ). Virus was propagated on Vero cells and viral titers were determined by cytopathogenic effect and expressed as 50\% tissue culture infectious dose (TCID50)/ $\mathrm{mL}$. Aliquots of viral stock were stored at $-80^{\circ} \mathrm{C}$ until use.

2.3. Cytotoxicity Assays. The effect of SPs on cell viability of Vero cells was determined by MTT assay. The cells were cultured in 96-well plates at a density of $1.5 \times 10^{4}$ cells/well at $37^{\circ} \mathrm{C}$ in an atmosphere of $\mathrm{CO}_{2}$. After 1 day of incubation, increasing concentrations of SPs diluted in DMEM were added; after $48 \mathrm{~h}$ of incubation the media were replaced with $22 \mu \mathrm{L}$ of $2.5 \mathrm{mg} / \mathrm{mL}$ MTT dissolved in phosphate-buffered saline (PBS). After $1 \mathrm{~h} 30 \mathrm{~min} 150 \mu \mathrm{L}$ of DMSO was added and incubated at room temperature for $15 \mathrm{~min}$. The optical density (OD450 nm) was measured using a microplate reader (Multiskan FC, Thermo, USA). Cell viability was expressed by percentage as the mean value of three independent experiments considering control cells absorbance as $100 \%$ viable. $\mathrm{CC}_{50}$ was the concentration of the test substances that inhibited the Vero cells growth by $50 \%$ compared with the growth of the untreated cells.

2.4. Syncytia Reduction Assays. The antiviral activity of the SPs was evaluated by syncytia reduction assays. Vero cells seeded in 12-well plates were treated with different concentrations of SPs $(0.01-5 \mu \mathrm{g} / \mathrm{mL})$ and infected with $\mathrm{MeV}(1 \times$ $10^{3.5}$ TCID50 of Edmonston strain) at the same time. After virus adsorption for $1 \mathrm{~h}$ at $37^{\circ} \mathrm{C}$ the medium was removed and monolayers were washed with PBS, after which the corresponding concentrations of SPs were added again. Each concentration was tested using three culture wells per PS concentration per experiment; the experiments were performed by triplicate. After incubation of 48 or $72 \mathrm{~h}$ at $37^{\circ} \mathrm{C}$ in a $5 \% \mathrm{CO}_{2}$ incubator monolayers were fixed with methanol:acetone $(1: 1)$ and stained with $1 \%$ crystal violet. Syncytia were counted and the result was expressed as a percentage of the number of syncytia observed in viral control monolayers (untreated cultures); $\mathrm{IC}_{50}$ was determined from dose-response curves. The selectivity index (SI) values were calculated as $\mathrm{CC}_{50} / \mathrm{IC}_{50}$. SPs showing the best SI were selected for the subsequent experiments.

2.5. Quantitative Real-Time PCR. Total RNA was isolated from treated Vero cells using RNAzol $^{\circledR}$ RT (MRC Inc., USA). Reverse transcription was performed using the High Capacity cDNA Reverse Transcription Kit (Applied Biosystems, USA) and the viral genome was amplified with specific primers (MeVF: $5^{\prime}$ GAGGGTCAAACAGAGTCGAG 3', MeVR: $5^{\prime}$ CGGTTGGAAGATGGGCAG $3^{\prime}$ ) that amplified a $95 \mathrm{nt}$ fragment. The real-time PCR was carried out using SensiFAST ${ }^{\text {TM }}$ SYBR $^{\circledR}$ No-ROX Kit (BIOLINE, USA) and the Chromo4 ${ }^{\mathrm{TM}}$ Real-Time PCR Detector (Bio-Rad, USA) with the following procedures: $95^{\circ} \mathrm{C}$ for $2 \mathrm{~min}$, followed by 50 cycles of $95^{\circ} \mathrm{C}$ for $2 \mathrm{~s}, 60^{\circ} \mathrm{C}$ for $10 \mathrm{~s}$, and $72^{\circ} \mathrm{C}$ for $20 \mathrm{~s}$. The number of viral copies was calculated by using a standard curve. Serial 10-fold dilutions of a synthetic oligonucleotide encompassing the target measles gene were used to establish the standard curves.

2.6. Evaluation of SPs Synergy. Potential synergistic effects of selected SPs on $\mathrm{MeV}$ infection were evaluated using syncytia reduction assays. Each combination was tested on its corresponding $\mathrm{IC}_{75}, \mathrm{IC}_{50}$, and $\mathrm{IC}_{25}$ values. The synergistic effect of SPs was calculated by using a combination index (CI) described previously by Chou [33] and CompuSyn software. CI was calculated from the data as a measure of the interaction among drugs. CI values lower than 0.9 indicate synergy, CI values from 0.9 to 1.1 indicate an additive effect, and CI values higher than 1.1 indicate antagonism. Combinations with synergistic antiviral effect were selected and qPCR assays were performed in order to confirm the inhibitory effect as described above.

2.7. Time of Addition Assay. Vero cell monolayers were infected with $\mathrm{MeV}$. SPs were added at a concentration of $5 \mu \mathrm{g} / \mathrm{mL}$ at different times of infection: $60 \mathrm{~min}$ before infection and $0,15,30,60$, and $120 \mathrm{~min}$ after infection. Thereafter, for each treatment, cells were incubated with SP for $1 \mathrm{~h}$ and then washed three times with PBS. Monolayers were fixed with methanol : acetone after incubation for 48 or $72 \mathrm{~h}$ at $37^{\circ} \mathrm{C}$ and $5 \% \mathrm{CO}_{2}$ and stained with $1 \%$ crystal violet; syncytia were counted subsequently.

2.8. Viral Penetration Assay. Virus penetration into Vero cells was evaluated according to the method reported by Huang and Wagner [34] with some modifications [18]. Vero cell 


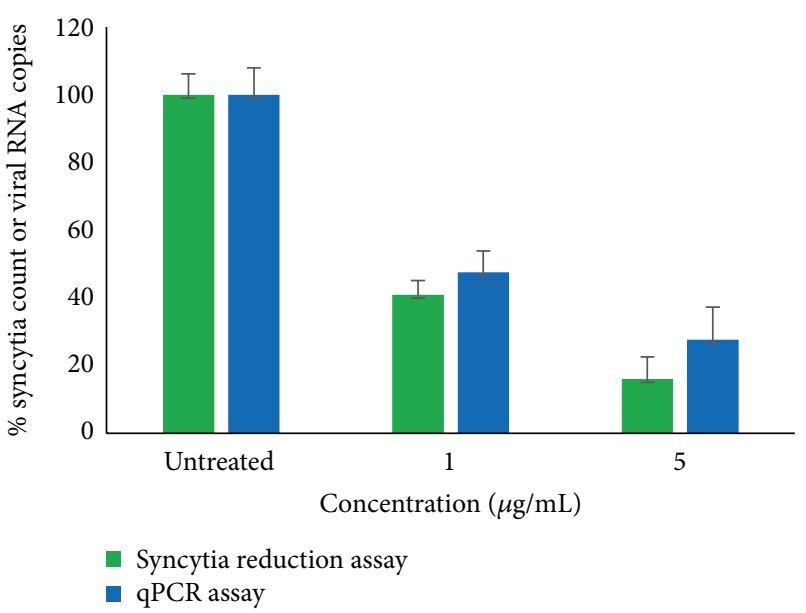

(a)

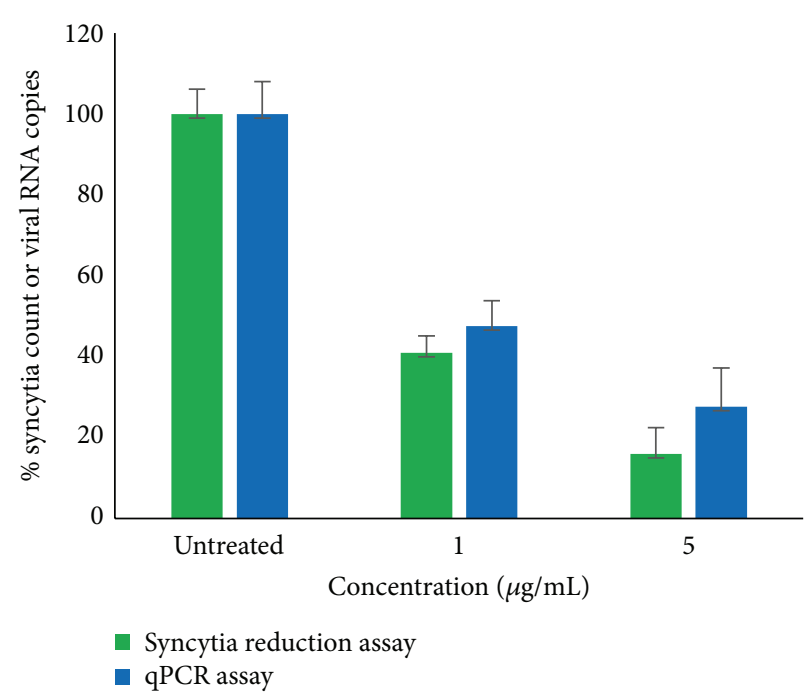

(b)

FIGURE 1: Confirmation of antiviral activity of Eisenia arborea (a) and Solieria filiformis (b) SPs at their best inhibitory concentrations by syncytia reduction and qPCR assays. Syncytia count and viral RNA copies number are given in \% of the untreated control values.

monolayers precooled at $4^{\circ} \mathrm{C}$ for $3 \mathrm{~h}$ were infected with $\mathrm{MeV}$ at $4^{\circ} \mathrm{C}$ for $1 \mathrm{~h}$ in the absence of SP. After washing three times with ice-cold PBS, different concentrations of SP were added to the monolayers, and the temperature was shifted to $37^{\circ} \mathrm{C}$. After $1 \mathrm{~h}$ of incubation at $37^{\circ} \mathrm{C}$, the cells were treated with $40 \mathrm{mM}$ citrate buffer $(\mathrm{pH} 3.0$ ) to inactivate unpenetrated viruses. Buffer was replaced by culture medium and the cells were incubated for 48 or $72 \mathrm{~h}$ at $37^{\circ} \mathrm{C}$ and $5 \% \mathrm{CO}_{2}$ and stained with $1 \%$ crystal violet; syncytia were counted subsequently.

2.9. Statistical Analysis. The variables (tested by triplicate in each experiment that were in turn repeated at least three times) were submitted to a one-way analysis of variance followed by Dunnett's test (SPSS software, $\alpha=0.05$ ). $\mathrm{CC}_{50}$ and $\mathrm{IC}_{50}$ values were determined by probit regression analysis.

\section{Results}

3.1. Cytotoxicity and Antiviral Activity of SPs. The MTT assay indicated no cytotoxicity for any of the SPs at concentrations from 0.1 to $1500 \mu \mathrm{g} / \mathrm{mL}$ up to 2 days (data not shown).

Antiviral activity of SPs against $\mathrm{MeV}$ was evaluated by syncytia reduction inhibition assays at concentrations of 0.01 , $0.1,1$, and $5 \mu \mathrm{g} / \mathrm{mL}$ of each compound (data not shown). All tested compounds showed significant antiviral activity, but only compounds with the best SI values were selected for the subsequent experiments. As shown in Table 1, SPs of Eisenia arborea and Solieria filiformis exhibited antiviral activity at the lowest concentrations $\left(\mathrm{IC}_{50} 0.275 \mu \mathrm{g} / \mathrm{mL}\right.$ and $0.985 \mu \mathrm{g} / \mathrm{mL}$, resp.) without cytotoxic effect at concentrations of 0.1 to $1500 \mu \mathrm{g} / \mathrm{mL}$. Therefore, SPs of Eisenia arborea and Solieria filiformis were selected based on their SI and antiviral activity for the combination experiments.
TABLE 1: Cytotoxic effect, antiviral activity, and selectivity index of SPs.

\begin{tabular}{lccc}
\hline Algae $^{\mathrm{a}}$ & $\mathrm{CC}_{50}(\mu \mathrm{g} / \mathrm{mL})^{\mathrm{b}}$ & $\mathrm{IC}_{50}(\mu \mathrm{g} / \mathrm{mL})^{\mathrm{c}}$ & $\mathrm{SI}^{\mathrm{d}}$ \\
\hline Macrocystis pyrifera & $>1500$ & 1.00 & $>1500$ \\
Eisenia arborea & $>1500$ & 0.275 & $>5454.54$ \\
Pelvetia compressa & $>1500$ & 1.00 & $>1500$ \\
Ulva intestinalis & $>1500$ & 3.6 & $>416.7$ \\
Solieria filiformis & $>1500$ & 0.985 & $>1522.84$ \\
\hline
\end{tabular}

${ }^{\mathrm{a}}$ Algal sulfated polysaccharide extract. ${ }^{\mathrm{b}}$ Concentration of test compound $(\mu \mathrm{g} / \mathrm{mL})$ that reduced Vero cell viability by $50 \% .{ }^{\circ}$ Concentration of a test compound that reduced the number of $\mathrm{MeV}$ syncytia in Vero cells by $50 \%$.

${ }^{\mathrm{d}}$ Selectivity index value.

Antiviral effect of selected SPs was confirmed by qPCR assays, as shown in Figure 1. Inhibitory effect of Eisenia arborea and Solieria filiformis SP was tested at the best inhibitory concentrations $(1 \mu \mathrm{g} / \mathrm{mL}$ and $5 \mu \mathrm{g} / \mathrm{mL}$ for both SPs). Results of qPCR assays were consistent with the results observed by syncytia reduction inhibition assays.

3.2. Characterization of SPs. Infrared spectroscopy has been used for the qualitative characterization of carrageenans and has proven to be a valuable tool for the characterization of sulfated oligosaccharides [35]. FT-IR and NMR spectra analyses of selected SPs extracts were performed. The FT-IR spectrum of Solieria filiformis extract (Figure 2(a)) indicates the presence of a typical $\iota$-carrageenan type. Characteristics signal bands are indicated: 3,6 anhydrogalactose-2-sulfate $\left(804 \mathrm{~cm}^{-1}\right)$ characteristic of $\iota$-carrageenan; galactose-4sulfate $\left(846 \mathrm{~cm}^{-1}\right)$ signal present in $\kappa$ - and $\iota$-carrageenan. The signal between 1210 and $1260 \mathrm{~cm}^{-1}$ is common to all types of compounds containing sulfate. 


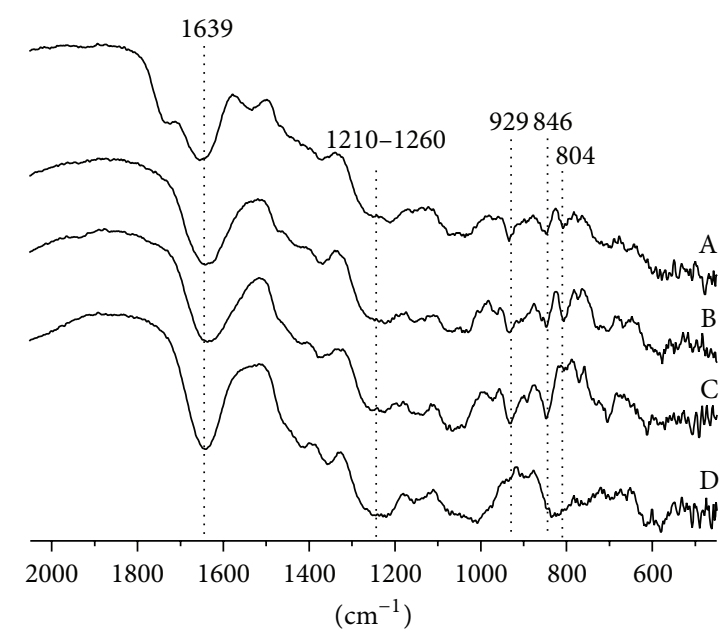

(a)

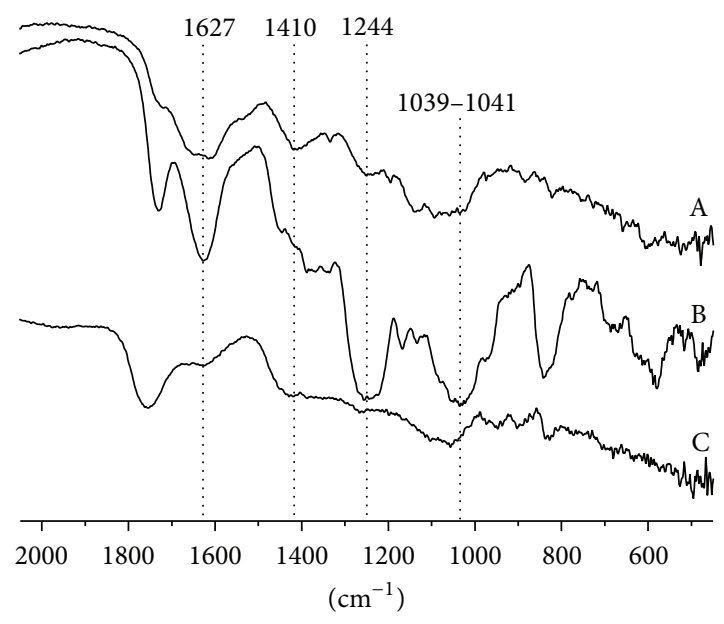

(b)

Figure 2: (a) Infrared spectra of (A) Solieria filiformis aqueous extract, (B) $\iota$-carrageenan, (C) $\kappa$-carrageenan, and (D) $\lambda$-carrageenan. (b) Infrared spectra of (A) Eisenia arborea aqueous extract, (B) fucoidan, and (C) alginic acid.

${ }^{13} \mathrm{C}-\mathrm{NMR}$ spectroscopy has been highly recommended for distinguishing the polysaccharides of the agar and carrageenan group [36]. Spectrum and expansion ${ }^{13} \mathrm{C}-\mathrm{NMR}$ of the S. filiformis extract (Figure 3(a)) showed signals at 20 and $60 \mathrm{ppm}$ typical of residual ethanol. Carbohydrates signals (63.79-104.66 ppm) observed, particularly two upfieldshifted signals (94.51 and $104.66 \mathrm{ppm})$, suggest that the molecule has two anomeric carbons. Overall its spectrum showed the presence of the $\iota$-carrageenan. The next assignment is the mapping of the carbon signals of the molecule. Carbons of 2-sulfate-3,6-anhydrogalactose are $94.51(\mathrm{C1})$, 77.44 (C2), 80.25 (C3), 80.84 (C4), 79.49 (C5), and 72.33 (C6) ppm [37]. Carbons of 4-sulfate-galactose are 104.66 (C1), 71.68 (C2), 79.27 (C3), 74.51 (C4), 77.27 (C5), and 63.79 (C6) ppm [37]. Sulfate content of S. filiformis showed $21.14 \%$ $( \pm 0.056)$ of total sulfate and total polysaccharide determination resulted in $91 \%$ of polysaccharide.

The FT-IR spectrum of Eisenia arborea extract (Figure 2(b)) indicates the presence of a mixture of fucoidan and alginic acid. Characteristics signal bands are indicated: carboxylate vibrations $\left(1627\right.$ and $1410 \mathrm{~cm}^{-1}$ ) can be attributed to uronic acids. Stretching vibrations at $1039-1041 \mathrm{~cm}^{-1} \mathrm{can}$ be assigned to pyranose ring from guluronic and mannuronic acid residues. The broad band at $1244 \mathrm{~cm}^{-1}$ indicates the presence of sulfated ester groups, which are characteristic in fucoidans. ${ }^{13} \mathrm{C}-\mathrm{NMR}$ spectrum of $E$. arborea extract (Figure 3(b)) showed typical signals of alginate ranging from 66.04 to $177.68 \mathrm{ppm}$. The signal at $66.04 \mathrm{ppm}$ is characteristic of carbon-2 of guluronic acid (G) [38]. The signals at 72.51, $72.79,74.07,78.90,80.82,102.81,102.93$, and 177.68 ppm correspond to repeating blocks of mannuronic (M) and guluronic acid [39]. The signals at 102.81 and 102.93 ppm may indicate the presence of two repeating units, one of MMM and another of GMM [39]. Sulfate content of E. arborea showed $12.85 \%$ $( \pm 0.346)$ of total sulfate.
3.3. Combined Antiviral Effect of SPs. The combined effect of SPs of Eisenia arborea and Solieria filiformis on $\mathrm{MeV}$ infections was examined: each SP was tested at different concentrations combining its corresponding $\mathrm{IC}_{25}, \mathrm{IC}_{50}$, and $\mathrm{IC}_{75}$ values. $\mathrm{E}_{25}, \mathrm{E}_{50}$, and $\mathrm{E}_{75}$ correspond to $\mathrm{IC}_{25}, \mathrm{IC}_{50}$, and $\mathrm{IC}_{75}$ values of Eisenia arborea SPs and $\mathrm{S}_{25}, \mathrm{~S}_{50}$, and $\mathrm{S}_{75}$ correspond to the respective values of Solieria filiformis SP (Table 2). Syncytia reduction assay results were expressed in relative syncytia percentage according to the number of syncytia in viral control. Best inhibitory effect was observed for $E_{50}-S_{25}$ combination.

The evaluation of drug synergism based on a medianeffect equation has been extensively used in the literature. CI values of SPs combinations were calculated as described previously using the CompuSyn software and are given in Table 2. Median-effect and the normalized isobologram generated with the software determined the presence of three synergistic combinations, represented by points below the lines at normalized isobologram (Figure 4).

Results showed strong synergistic effects at low concentrations combinations $\left(\mathrm{E}_{50}-\mathrm{S}_{25}, \mathrm{E}_{25}-\mathrm{S}_{50}\right.$, and $\left.\mathrm{E}_{25}-\mathrm{S}_{25}\right)$ and antagonism at high concentrations combinations $\left(E_{25}-S_{75}\right.$, $\mathrm{E}_{50}-\mathrm{S}_{50}, \mathrm{E}_{50}-\mathrm{S}_{75}, \mathrm{E}_{75}-\mathrm{S}_{25}, \mathrm{E}_{70}-\mathrm{S}_{50}$, and $\left.\mathrm{E}_{75}-\mathrm{S}_{75}\right)$. Combinations with synergistic effect were selected and qPCR assays were performed. As shown in Figure 5 the inhibitory effect of the synergistic combinations was confirmed. These data were consistent with results observed by syncytia reduction inhibition assays.

3.4. Effect of SPS on Viral Infection at Different Times of Addition. In order to determine which step of the $\mathrm{MeV}$ cycle was targeted by SPs, "time of addition" experiments were performed in Vero cells infected with $\mathrm{MeV}$ and exposed to PS at different times of infection. The most efficient inhibition by S. filiformis was observed in early phases of infection, 0 and 


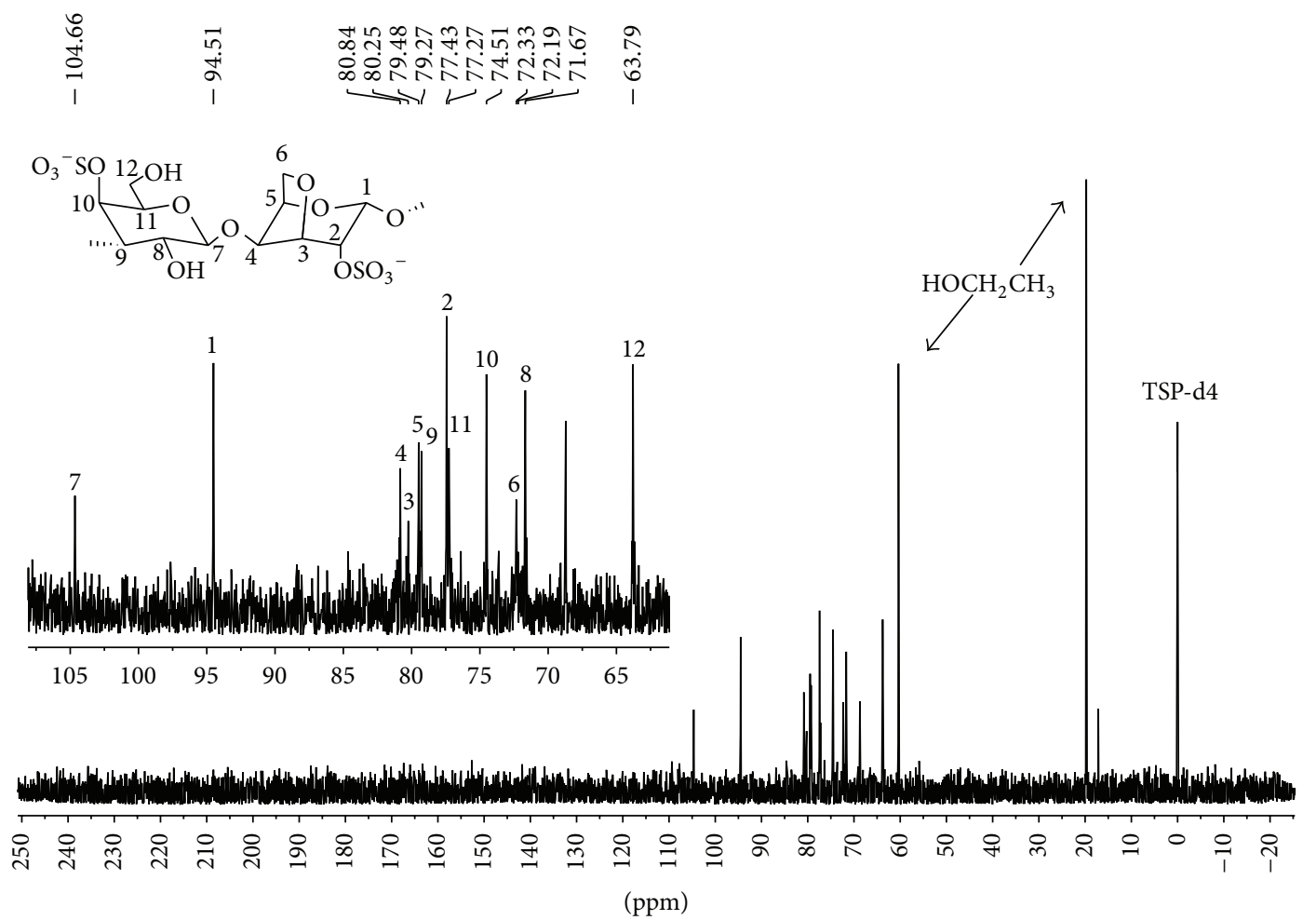

(a)

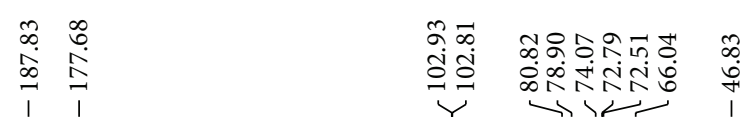

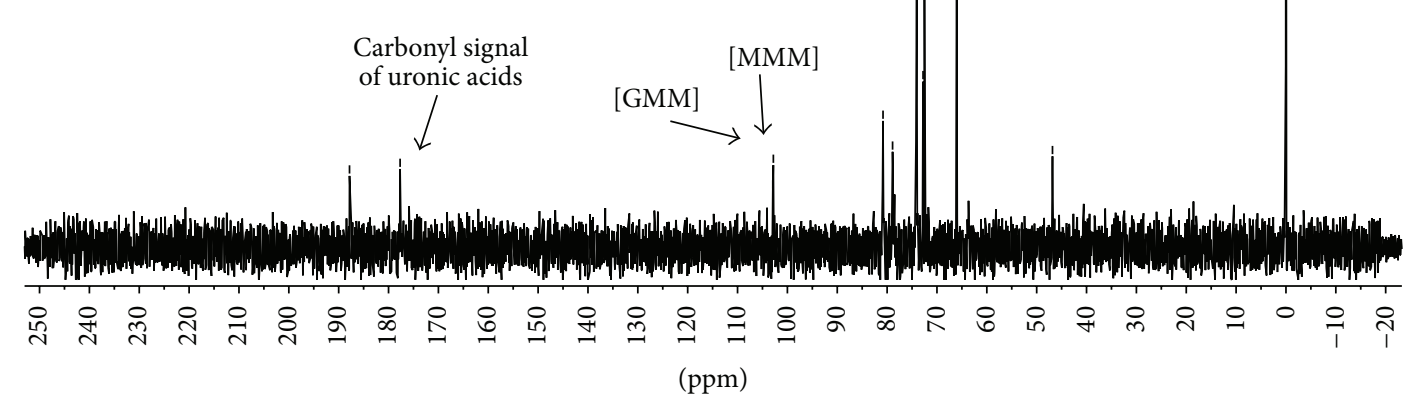

(b)

Figure 3: (a) Spectrum and expansion ${ }^{13} \mathrm{C}$-NMR of the aqueous extract of $S$. filiformis. (b) ${ }^{13} \mathrm{C}$-NMR spectrum of the aqueous extract of $E$. arborea. 
TABLE 2: Synergistic effects of SPs on MeV infection.

\begin{tabular}{|c|c|c|c|c|c|c|}
\hline \multirow{2}{*}{$\begin{array}{l}\text { Compounds } \\
\text { combination }\end{array}$} & \multicolumn{2}{|c|}{ Compound concentration $(\mu \mathrm{g} / \mathrm{mL})$} & \multirow{2}{*}{$\begin{array}{l}\% \text { relative syncytia formation in presence of } \\
\text { the different SPs combinations }\end{array}$} & \multirow{2}{*}{ SD } & \multirow{2}{*}{ CI } & \multirow{2}{*}{ Description } \\
\hline & Eisenia arborea & Solieria filiformis & & & & \\
\hline $\mathrm{IC}_{75}-\mathrm{IC}_{75}$ & 2.98 & 3.027 & 34.5 & 4.4 & 10.59 & Antagonism \\
\hline $\mathrm{IC}_{75}-\mathrm{IC}_{50}$ & 2.98 & 0.985 & 26.4 & 5.6 & 3.08 & Antagonism \\
\hline $\mathrm{IC}_{75}-\mathrm{IC}_{25}$ & 2.98 & 0.011 & 33 & 7.3 & 1.47 & Antagonism \\
\hline $\mathrm{IC}_{50}-\mathrm{IC}_{75}$ & 0.275 & 3.027 & 28.4 & 4.1 & 3.71 & Antagonism \\
\hline $\mathrm{IC}_{50}-\mathrm{IC}_{50}$ & 0.275 & 0.985 & 32 & 5.9 & 1.88 & Antagonism \\
\hline $\mathrm{IC}_{50}-\mathrm{IC}_{25}$ & 0.275 & 0.011 & 4 & 3.2 & 0.001 & Synergism \\
\hline $\mathrm{IC}_{25}-\mathrm{IC}_{75}$ & 0.01 & 3.027 & 22.5 & 6.6 & 1.85 & Antagonism \\
\hline $\mathrm{IC}_{25}-\mathrm{IC}_{50}$ & 0.01 & 0.985 & 16.7 & 7.1 & 0.31 & Synergism \\
\hline $\mathrm{IC}_{25}-\mathrm{IC}_{25}$ & 0.01 & 0.011 & 39.4 & 2.5 & 0.05 & Synergism \\
\hline
\end{tabular}

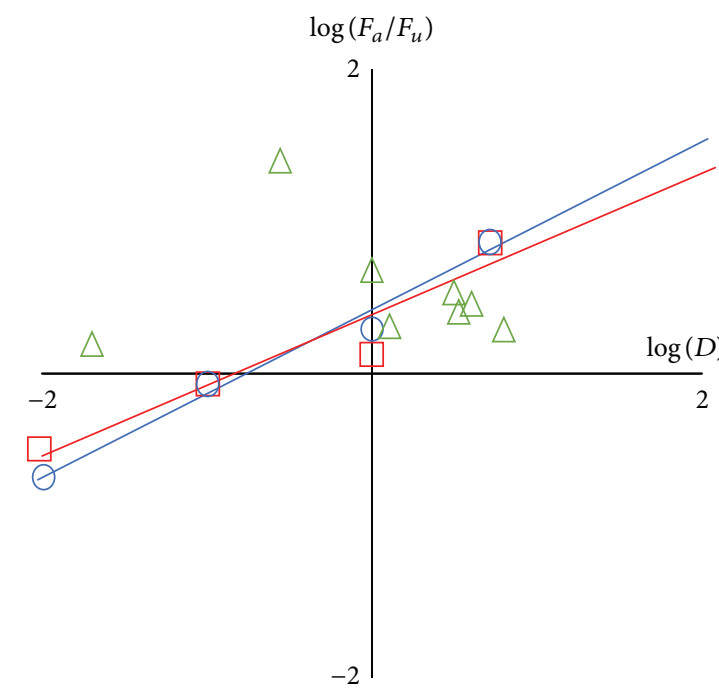

$\bigcirc$ Sf
$\square$ Ea
$\triangle$ Comb

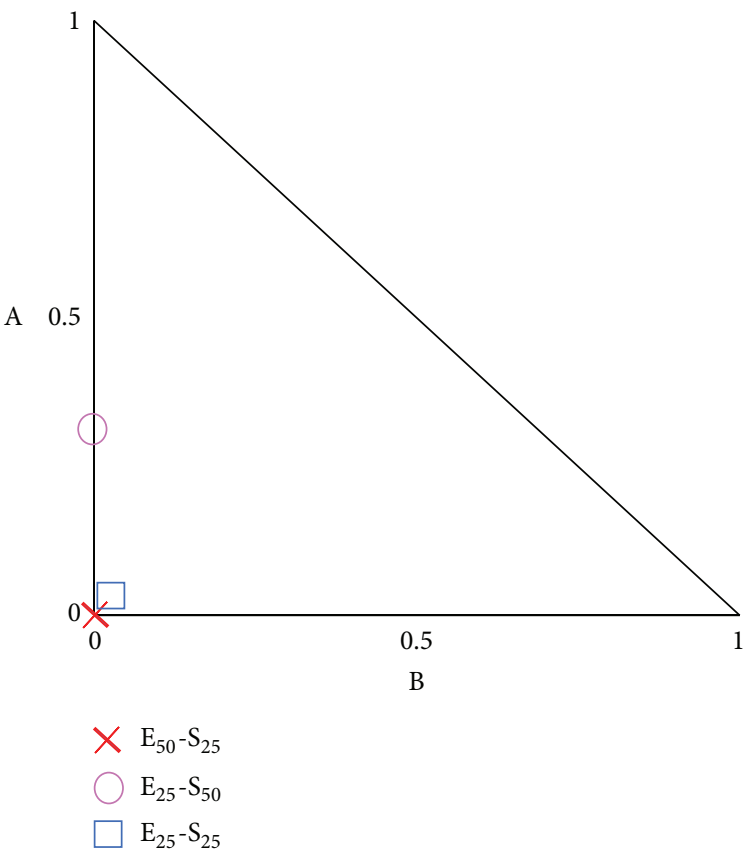

(b)

Figure 4: Analysis of Eisenia arborea and Solieria filiformis combinations. (a) Median-effect plot for combinations of Eisenia arborea and Solieria filiformis was generated with the CompuSyn software ( $F_{a}$, affected fraction; $F_{u}$, unaffected fraction; $D$, concentration of SP used; Sf Solieria filiformis SP; Ea, Eisenia arborea SP; Comb, Eisenia arborea and Solieria filiformis combinations). (b) Normalized isobologram plots for Sf and Ea at nonconstant combination ratios. For each SP different combinations of various concentrations based on $\mathrm{IC}_{25}$, IC $\mathrm{I}_{50} \mathrm{values}$ were tested and combination index (CI) values were determined using the CompuSyn software. CI values, represented by points below the lines, indicate synergy.

15 min after infection (Figure 6); syncytia inhibition before infection and $30 \mathrm{~min}$ after infection was not significant. $E$. arborea showed the most efficient inhibition 1 hour before infection and 0 and $15 \mathrm{~min}$ after infection. At 30, 60, and 120 min after infection, a minimal syncytia inhibition by $E$. arborea was still observed.

\subsection{Effect of Fucoidan on Viral Penetration into Host Cells.} Viral penetration assays were performed to determine whether entry events downstream of virus binding were inhibited by SPs. Vero cells were plated and incubated with $\mathrm{MeV}$ at $4^{\circ} \mathrm{C}$ for $1 \mathrm{~h}$ to allow virus binding but prevent viral internalization. Unbound virus was inactivated and SPs $(1 \mu \mathrm{g} / \mathrm{mL}$ or $5 \mu \mathrm{g} / \mathrm{mL})$ were added to the cells and incubated at $37^{\circ} \mathrm{C}$. Figure 7 shows that SP from S. filiformis $(5 \mu \mathrm{g} / \mathrm{mL})$ significantly decreased viral infection by $58 \%$, while SPs from E. arborea $(5 \mu \mathrm{g} / \mathrm{mL})$ decreased viral infection only by $24 \%$, when compared with the findings in infected cells in the absence of treatment.

\section{Discussion}

Since the first studies by Gerber in 1958 showing the inhibition of mumps and influenza $B$ virus by marine algae 


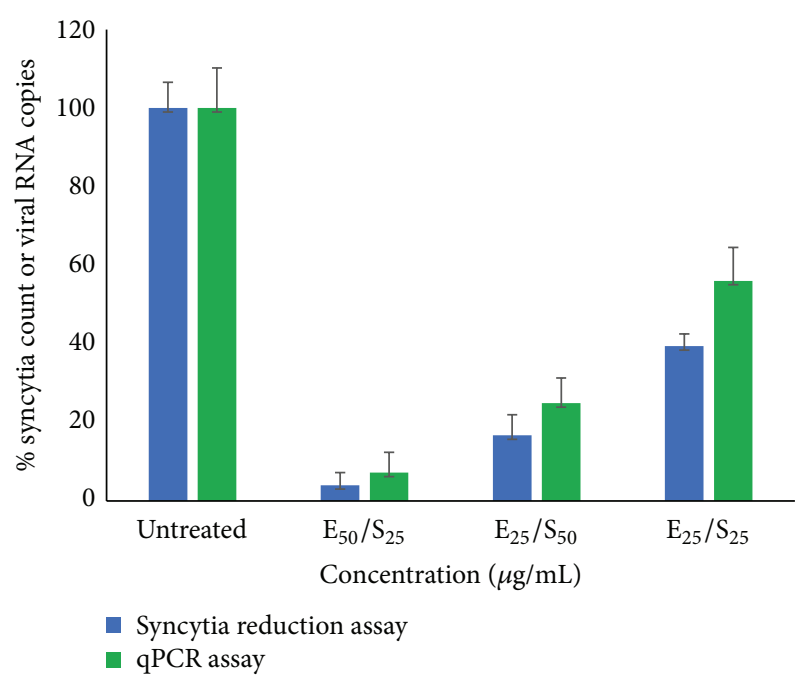

FIGURE 5: Antiviral activity confirmation by qPCR of the RNA extracted from Vero cells infected with $\mathrm{MeV}$ and cultivated in presence of synergistic SPs combinations. $\mathrm{E}_{25}$ and $\mathrm{E}_{50}$ are the SPs concentrations corresponding to $\mathrm{IC}_{25}$ and $\mathrm{IC}_{50}$ values of Eisenia arborea SPs. $\mathrm{S}_{25}$ and $\mathrm{S}_{50}$ concentrations correspond to the respective IC values of Solieria filiformis SP.

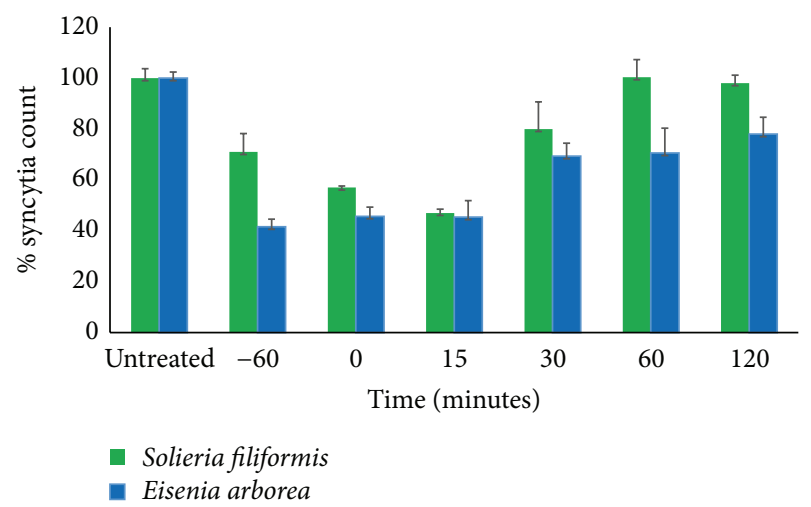

FIGURE 6: Time of addition experiments. Antiviral activity of SP was tested at different times of infection and analyzed by syncytia inhibition assays. SPs were added at $60 \mathrm{~min}$ before infection and $0,15,30,60$, and $120 \mathrm{~min}$ after infection. The data are expressed as relative syncytia count (\%) compared to that of untreated virusinfected control cells, which was defined as $100 \%$. The data shown are the mean \pm SD of triplicate experiments.

polysaccharides, increased efforts and research have been carried out in this field [13]. Previous studies have also demonstrated no cytotoxicity of SPs isolated from certain seaweed species [40]. The absence of cytotoxicity to the host cells is one of the principal challenges in the development of new antivirals.

Eisenia arborea, an edible brown alga used in folk medicine in Japan, is the kelp species with the largest and most southerly latitudinal distribution on the North Pacific East Coast [41,42]. Researches on Eisenia biological activities have been focused on the evaluation of their polyphenolic compounds [43]. To our knowledge, the antiviral effects of

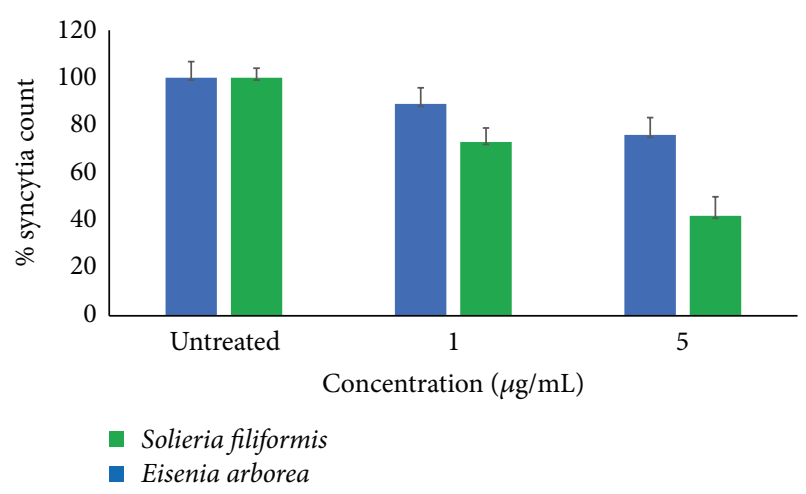

FIGURE 7: Effect of SPs on viral penetration. Vero cells were infected with $\mathrm{MeV}$ at $4^{\circ} \mathrm{C}$ in the absence of SPs and then shifted to $37^{\circ} \mathrm{C}$ to permit penetration of the adsorbed virus in the presence of SPs. Antiviral effect of SPs was evaluated using syncytia inhibition assays. The data shown are the mean \pm SD of triplicate experiments.

Eisenia arborea extracts have never been tested before. In this study, the extract of Eisenia arborea is rich in fucoidans and alginates and also showed the best SI of the five seaweed extracts (Table 1). Previous chemical characterization of Mexican E. arborea extracts also reported the presence of alginates, with higher yields than the one reported in this study [44]. Alginates with antiviral effects have been previously tested against HIV, IAV, and HBV, showing a potent antiviral activity [4]. Antiviral activity of fucoidan has been also reported in vitro and in vivo against many RNA and DNA viruses such as HIV, HSV1-2, dengue virus, and influenza virus [39, 45-47].

Macrocystis pyrifera has been harvested since 1956 along the Pacific coast of Baja California and exported to the United States for the production of alginates [48]. SPs extracts of Mexican Macrocystis pyrifera showed a significant antiviral effect but were not selected for subsequent assays because of their $\mathrm{IC}_{50}$ value (Table 1). Previous studies with crude dialyzed extracts of Macrocystis pyrifera have shown antiviral effects against VSV, with the fucoidan being responsible for these results [49].

In this study, antiviral effects of the extract from Solieria filiformis display the second lowest $\mathrm{IC}_{50}$ among the analyzed extracts. In vitro studies have reported antiviral properties of carrageenans against DNA and RNA viruses [21,50]. Recently it has been shown that carrageenan (Rong Yuan F.F.I. Co., Ltd.) can inhibit influenza virus A/Swine/Shandong/731/2009 H1N1 (SW731) responsible for the influenza pandemic of 2009. Carrageenans can significantly inhibit SW731 replication by interfering with different steps of viral replication, including adsorption, transcription, and expression of the viral proteins; however, they act especially by inhibiting the interactions between the viral receptor (HA) and the target cell [51]. Sulfate content analysis and total polysaccharide determination of $S$. filiformis extract resulted in $21.14 \%$ $( \pm 0.056)$ total sulfate and $91 \%$ polysaccharide; these data are consistent with previous reports [52]. Degree of sulfation has a major impact on the antiviral activity of polysaccharides, including carrageenans [53]. 
In relation to the combination therapy approach used in this study, results showed a strong synergistic effect at low concentrations combinations of SPs and antagonism at high concentrations combinations. Our results determined that low concentrations combinations $(0.0274 \mu \mathrm{g} / \mathrm{mL}$ and $0.011 \mu \mathrm{g} / \mathrm{mL}$ of E. arborea and S. filiformis, resp.) exhibited the higher inhibitory effect $(96 \%)$ in comparison to the individual effect of SP (50\% of inhibition with $0.275 \mu \mathrm{g} / \mathrm{mL}$ and $0.985 \mu \mathrm{g} / \mathrm{mL}$ of E. arborea and S. filiformis, resp.). Synergistic effect observed in this study has been also reported for the sulfated polysaccharides from Fucus vesiculosus in combination with AZT against HIV [54]. Furthermore, this effect has been also observed with acyclovir in combination with 3, 19isopropylideneandrographolide against herpes simplex virus (wild type) and drug-resistant strains. Low concentrations of these compounds were required for a complete inhibition of DNA replication and late protein synthesis of HSV-1 wild type and drug-resistant HSV-1 [55]. The combined effect of nitazoxanide with neuraminidase inhibitors against influenza A viruses tested in vitro suggests that regimens that combine neuraminidase inhibitors and nitazoxanide exert synergistic anti-influenza effects [56]. In contrast, antagonistic effects at high concentrations were observed in our study; this antagonism of SPs was previously observed in a combination of ulvan and fucoidan against NDV infection [23]. Particular chemical features of SPs like chain ramifications could explain antagonism effects of SPs. Moreover, carbohydrate to carbohydrate interactions could be responsible to adhesion events; these aggregates have been previously observed in marine sponges [57].

To understand if a synergistic effect was related to different modes of action of the tested SPs, viral penetration and time of addition assays were performed. Results suggested the possibility that SP from S. filiformis inhibits postbinding events, because best inhibition effect was observed at 0 and 15 minutes after viral infection (Figure 6). To support this idea, a viral penetration assay was performed (Figure 7), and results show the best antiviral effect after viral adsorption. Our results are in agreement with those observed by ElizondoGonzalez et al. [18], who demonstrated the ability of fucoidan from C. okamuranus to be responsible for the antiviral activity against Newcastle disease virus, suggesting that fucoidan inhibits viral penetration into host cells, must probably by blocking the F protein.

Similar results were also observed by Bouhlal et al. [58], who suggested that carrageenans can inhibit DENV replication by interfering viral entrance, but they also suggested that SPs could avoid viral adsorption into the cell as a second mode of action. This mode of action could be similar to the mechanism observed with SPs of E. arborea. Alginates and fucoidan of $E$. arborea were able to show the best antiviral effect 1 hour before infection and this effect lasted up to 0-15 minutes after infection. Although both SPs, from $S$. filiformis and E. arborea, exhibited antiviral activity at 0 and $15 \mathrm{~min}$ after infection, only E. arborea showed inhibitory effect at $60 \mathrm{~min}$. This result suggests the capability of these SPs to avoid viral adsorption to the cell; these data were confirmed by viral penetration assays where we observed less antiviral activity after viral attachment to the cell. More recent studies have demonstrated that fucoidans exhibit their antiviral activity when the compound is present during the virus adsorption period by blocking the interaction of viruses to the cells [59].

SPs tested in this study exhibit the best antiviral effect at different stages of infection: viral penetration and viral adsorption (S. filiformis and E. arborea, resp.). Multiple-drug antiviral therapy with two or more drugs that target different proteins or act in different stages of infection may decrease drug resistance and may enhance clinical outcomes by allowing a reduction of individual drug doses, thus decreasing dose-related drug toxicity [60].

\section{Conclusions}

In this study sulfated polysaccharides from Mexican seaweed showed antiviral activity against measles virus. Due to the lack of cytotoxicity at inhibitory concentrations, as indicated by the selectivity index, potential application can be found for these SPs. Eisenia arborea and Solieria filiformis extracts showed the higher antiviral activity and were selected to determine their combined effect. Synergistic effect was observed at the lowest concentrations tested for each SP of these species. Results suggest that SPs combined in this study are acting at different level of first stages in viral infection. Synergistic therapeutic effect allows dose and toxicity reduction and would minimize or delay the induction of antiviral resistance. Sulfated polysaccharides of Mexican seaweed are potential candidates for the development of new antiviral drugs that can help to control viral infection diseases.

\section{Competing Interests}

The authors declare that they have no competing interests.

\section{Acknowledgments}

The authors thank E. Hernández, E. Caamal, and C. Chavéz for chemical analytical support; M. Maldonado for polysaccharide extraction support; I. Beamonte, R. Marcos, and R. Ojeda for seaweed collection support; S. Salcedo for the confirmation of seaweeds species identification; and K. Ledezma for cytotoxicity assays support. This work was supported by Consejo Nacional de Ciencia y Tecnología (CONACYT) Mexico (Project no. 10002-255075).

\section{References}

[1] R. O’Dor, P. Miloslavich, and K. Yarincik, "Marine biodiversity and biogeography—regional comparisons of global issues, an introduction," PLoS ONE, vol. 5, no. 8, Article ID el1871, 2010.

[2] C. Rebours, E. Marinho-Soriano, J. A. Zertuche-González et al., "Seaweeds: an opportunity for wealth and sustainable livelihood for coastal communities," Journal of Applied Phycology, vol. 26, no. 5, pp. 1939-1951, 2014.

[3] L. Wang, X. Wang, H. Wu, and R. Liu, "Overview on biological activities and molecular characteristics of sulfated polysaccharides from marine green algae in recent years," Marine Drugs, vol. 12, no. 9, pp. 4984-5020, 2014.

[4] A. Ahmadi, S. Zorofchian Moghadamtousi, S. Abubakar, and K. Zandi, "Antiviral potential of algae polysaccharides isolated 
from marine sources: a review," BioMed Research International, vol. 2015, Article ID 825203, 10 pages, 2015.

[5] S. Kraan, "Algal polysaccharides, novel applications and outlook," in Carbohydrates-Comprehensive Studies on Glycobiology and Glycotechnology, InTech, 2012.

[6] C. M. P. G. Dore, M. G. D. C. Faustino Alves, L. S. E. Pofírio Will et al., "A sulfated polysaccharide, fucans, isolated from brown algae Sargassum vulgare with anticoagulant, antithrombotic, antioxidant and anti-inflammatory effects," Carbohydrate Polymers, vol. 91, no. 1, pp. 467-475, 2013.

[7] B. W. S. Souza, M. A. Cerqueira, A. I. Bourbon et al., "Chemical characterization and antioxidant activity of sulfated polysaccharide from the red seaweed Gracilaria birdiae," Food Hydrocolloids, vol. 27, no. 2, pp. 287-292, 2012.

[8] V. Suresh, N. Senthilkumar, R. Thangam et al., "Separation, purification and preliminary characterization of sulfated polysaccharides from Sargassum plagiophyllum and its in vitro anticancer and antioxidant activity," Process Biochemistry, vol. 48, no. 2, pp. 364-373, 2013.

[9] P. Shao, X. Chen, and P. Sun, "Chemical characterization, antioxidant and antitumor activity of sulfated polysaccharide from Sargassum horneri," Carbohydrate Polymers, vol. 105, no. 1, pp. 260-269, 2014.

[10] C. O. Coura, I. W. F. de Araújo, E. S. O. Vanderlei et al., "Antinociceptive and anti-inflammatory activities of sulphated polysaccharides from the red seaweed Gracilaria cornea," Basic and Clinical Pharmacology and Toxicology, vol. 110, no. 4, pp. 335-341, 2012.

[11] C. A. Pujol, S. Ray, B. Ray, and E. B. Damonte, "Antiviral activity against dengue virus of diverse classes of algal sulfated polysaccharides," International Journal of Biological Macromolecules, vol. 51, no. 4, pp. 412-416, 2012.

[12] H. H. A. Gomaa and G. A. Elshoubaky, "Antiviral activity of sulfated polysaccharides carrageenan from some marine seaweeds," International Journal of Current Pharmaceutical Review and Research, vol. 7, no. 1, pp. 34-42, 2016.

[13] P. Gerber, J. D. Dutcher, E. V. Adams, and J. H. Sherman, "Protective effect of seaweed extracts for chicken embryos infected with influenza B or mumps virus," Experimental Biology and Medicine, vol. 99, no. 3, pp. 590-593, 1958.

[14] M. F. De Jesus Raposo, A. M. B. De Morais, and R. M. S. C. De Morais, "Marine polysaccharides from algae with potential biomedical applications," Marine Drugs, vol. 13, no. 5, pp. 29673028, 2015.

[15] S. F. Mohamed and F. A. Agili, "Antiviral sulphated polysaccharide from brown algae Padina pavonia characterization and structure elucidation," International Journal of ChemTech Research, vol. 5, no. 4, pp. 1469-1476, 2013.

[16] T. T. T. Thuy, B. M. Ly, T. T. T. Van et al., "Anti-HIV activity of fucoidans from three brown seaweed species," Carbohydrate Polymers, vol. 115, pp. 122-128, 2015.

[17] M. Kim, J. H. Yim, S.-Y. Kim et al., "In vitro inhibition of influenza A virus infection by marine microalga-derived sulfated polysaccharide p-KG03," Antiviral Research, vol. 93, no. 2, pp. 253-259, 2012.

[18] R. Elizondo-Gonzalez, L. E. Cruz-Suarez, D. Ricque-Marie, E. Mendoza-Gamboa, C. Rodriguez-Padilla, and L. M. TrejoAvila, "In vitro characterization of the antiviral activity of fucoidan from Cladosiphon okamuranus against Newcastle Disease Virus," Virology Journal, vol. 9, no. 1, article 307, 2012.

[19] L. M. Trejo-Avila, M. E. Morales-Martínez, D. Ricque-Marie et al., "In vitro anti-canine distemper virus activity of fucoidan extracted from the brown alga Cladosiphon okamuranus," VirusDisease, vol. 25, no. 4, pp. 474-480, 2014.

[20] G. Meiyu, L. Fuchuan, X. Xianliang, L. Jing, Y. Zuowei, and G. Huashi, "The potential molecular targets of marine sulfated polymannuroguluronate interfering with HIV-1 entry: interaction between SPMG and HIV-1 rgp120 and CD4 molecule," Antiviral Research, vol. 59, no. 2, pp. 127-135, 2003.

[21] C. B. Buck, C. D. Thompson, J. N. Roberts, M. Müller, D. R. Lowy, and J. T. Schiller, "Carrageenan is a potent inhibitor of papillomavirus infection," PLoS Pathogens, vol. 2, no. 7, pp. 0671-0680, 2006.

[22] A. Rodríguez, K. Kleinbeck, O. Mizenina et al., "In vitro and in vivo evaluation of two carrageenan-based formulations to prevent HPV acquisition," Antiviral Research, vol. 108, no. 1, pp. 88-93, 2014.

[23] J. A. Aguilar-Briseño, L. E. Cruz-Suarez, J.-F. Sassi et al., "Sulphated polysaccharides from Ulva clathrata and Cladosiphon okamuranus seaweeds both inhibit viral attachment/entry and cell-cell fusion, in NDV infection," Marine Drugs, vol. 13, no. 2, pp. 697-712, 2015.

[24] Y. Koizumi and S. Iwami, "Mathematical modeling of multidrugs therapy: a challenge for determining the optimal combinations of antiviral drugs," Theoretical Biology \& Medical Modelling, vol. 11, p. 41, 2014.

[25] W. J. Moss and D. E. Griffin, "Measles," The Lancet, vol. 379, no. 9811, pp. 153-164, 2012.

[26] W. J. Moss and D. E. Griffin, "Global measles elimination," Nature Reviews Microbiology, vol. 4, no. 12, pp. 900-908, 2006.

[27] G. Antonelli and O. Turriziani, "Antiviral therapy: old and current issues," International Journal of Antimicrobial Agents, vol. 40, no. 2, pp. 95-102, 2012.

[28] D. Robledo and Y. Freile-Pelegrín, "Prospects for the cultivation of economically important carrageenophytes in Southeast Mexico," Journal of Applied Phycology, vol. 23, no. 3, pp. 415-419, 2011.

[29] J. Xi, D. Shen, S. Zhao, B. Lu, Y. Li, and R. Zhang, "Characterization of polyphenols from green tea leaves using a high hydrostatic pressure extraction," International Journal of Pharmaceutics, vol. 382, no. 1-2, pp. 139-143, 2009.

[30] M. Tako, E. Yoza, and S. Tohma, "Chemical characterization of acetyl fucoidan and alginate from commercially cultured Cladosiphon okamuranus," Botanica Marina, vol. 43, no. 4, pp. 393-398, 2000.

[31] M. T. Ale, J. D. Mikkelsen, and A. S. Meyer, "Designed optimization of a single-step extraction of fucose-containing sulfated polysaccharides from Sargassum sp.", Journal of Applied Phycology, vol. 24, no. 4, pp. 715-723, 2012.

[32] S. G. Jackson and E. L. McCandless, "Simple, rapid, turbidometric determination of inorganic sulfate and/or protein," Analytical Biochemistry, vol. 90, no. 2, pp. 802-808, 1978.

[33] T.-C. Chou, “Theoretical basis, experimental design, and computerized simulation of synergism and antagonism in drug combination studies," Pharmacological Reviews, vol. 58, no. 3, pp. 621-681, 2006.

[34] A. S. Huang and R. R. Wagner, "Penetration of herpes simplex virus into human epidermoid cells," Proceedings of the Society for Experimental Biology and Medicine, vol. 116, no. 4, pp. 863869, 1964.

[35] P. Volery, R. Besson, and C. Schaffer-Lequart, "Characterization of commercial carrageenans by Fourier transform infrared spectroscopy using single-reflection attenuated total reflection," 
Journal of Agricultural and Food Chemistry, vol. 52, no. 25, pp. 7457-7463, 2004.

[36] V. L. Campo, D. F. Kawano, D. B. da Silva Jr., and I. Carvalho, "Carrageenans: biological properties, chemical modifications and structural analysis-a review," Carbohydrate Polymers, vol. 77, no. 2, pp. 167-180, 2009.

[37] F. Van De Velde, L. Pereira, and H. S. Rollema, "The revised NMR chemical shift data of carrageenans," Carbohydrate Research, vol. 339, no. 13, pp. 2309-2313, 2004.

[38] D. D. McIntyre, H. Ceri, and H. J. Vogel, "Nuclear magnetic resonance studies of the heteropolysaccharides alginate, Gum arabic and gum xanthan," Starch, vol. 48, no. 7-8, pp. 285-291, 1996.

[39] H. Grasdalen, B. Larsen, and O. Smisrod, " ${ }^{13}$ C-n.m.r. studies of monomeric composition and sequence in alginate," Carbohydrate Research, vol. 89, no. 2, pp. 179-191, 1981.

[40] S. Dinesh, T. Menon, L. E. Hanna, V. Suresh, M. Sathuvan, and M. Manikannan, "In vitro anti-HIV-1 activity of fucoidan from Sargassum swartzii," International Journal of Biological Macromolecules, vol. 82, pp. 83-88, 2016.

[41] Y. Sugiura, K. Matsuda, Y. Yamada et al., "Anti-allergic phlorotannins from the edible brown alga, Eisenia arborea," Food Science and Technology Research, vol. 13, no. 1, pp. 54-60, 2007.

[42] J. A. Zertuche-González, M. Sánchez-Barredo, J. M. GuzmánCalderón, and Z. Altamirano-Gómez, "Eisenia arborea J.E. Areschoug as abalone diet on an IMTA farm in Baja California, México," Journal of Applied Phycology, vol. 26, no. 2, pp. 957960, 2014.

[43] Q.-T. Le, Y. Li, Z.-J. Qian, M.-M. Kim, and S.-K. Kim, "Inhibitory effects of polyphenols isolated from marine alga Ecklonia cava on histamine release," Process Biochemistry, vol. 44, no. 2, pp. 168-176, 2009.

[44] D. L. Arvizu, Y. E. Rodríguez, G. Hernández, and J. I. Murillo, "Chemical constituents of Eisenia arbórea Areschoug from Baja California Sur, México," Investigaciones Marinas, vol. 35, no. 2, pp. 63-69, 2007.

[45] K. I. P. J. Hidari, N. Takahashi, M. Arihara, M. Nagaoka, K. Morita, and T. Suzuki, "Structure and anti-dengue virus activity of sulfated polysaccharide from a marine alga," Biochemical and Biophysical Research Communications, vol. 376, no. 1, pp. 91-95, 2008.

[46] K. Hayashi, T. Nakano, M. Hashimoto, K. Kanekiyo, and T. Hayashi, "Defensive effects of a fucoidan from brown alga Undaria pinnatifida against herpes simplex virus infection," International Immunopharmacology, vol. 8, no. 1, pp. 109-116, 2008.

[47] K. Hayashi, J.-B. Lee, T. Nakano, and T. Hayashi, "Anti-influenza A virus characteristics of a fucoidan from sporophyll of Undaria pinnatifida in mice with normal and compromised immunity," Microbes and Infection, vol. 15, no. 4, pp. 302-309, 2013.

[48] M. C. Valdez, E. S. Zaragoza, D. L. Belda, R. Marcos, and R. A. Ramírez, "Effect of climatic change on the harvest of the kelp Macrocystis Pyrifera on the Mexican Pacific coast," Bulletin of Marine Science, vol. 73, no. 3, pp. 545-556, 2003.

[49] A. M. S. Mayer, A. Diaz, A. Pesce, M. Criscuolo, J. F. Groisman, and R. M. de Lederkremer, "Biological activity in Macrocystis pyrifera from Argentina: sodium alginate, fucoidan and laminaran. III. Antiviral activity," Hydrobiologia, vol. 151-152, no. 1, pp. 497-500, 1987.
[50] Z. Luo, D. Tian, M. Zhou et al., " $\lambda$-Carrageenan P32 is a potent inhibitor of rabies virus infection," PLOS ONE, vol. 10, no. 10, Article ID e0140586, 2015.

[51] Q. Shao, Q. Guo, W. P. Xu, Z. Li, and T. T. Zhao, "Specific inhibitory effect of $\kappa$-carrageenan polysaccharide on swine pandemic 2009 H1N1 influenza virus," PLoS ONE, vol. 10, no. 5, Article ID e0126577, 2015.

[52] I. W. F. De Araújo, E. D. S. O. Vanderlei, J. A. G. Rodrigues et al., "Effects of a sulfated polysaccharide isolated from the red seaweed Solieria filiformis on models of nociception and inflammation," Carbohydrate Polymers, vol. 86, no. 3, pp. 12071215, 2011.

[53] T. Ghosh, K. Chattopadhyay, M. Marschall, P. Karmakar, P. Mandal, and B. Ray, "Focus on antivirally active sulfated polysaccharides: from structure-activity analysis to clinical evaluation," Glycobiology, vol. 19, no. 1, pp. 2-15, 2009.

[54] I. Sugawara, W. Itoh, S. Kimura, S. Mori, and K. Shimada, "Further characterization of sulfated homopolysaccharides as anti-HIV agents," Experientia, vol. 45, no. 10, pp. 996-998, 1989.

[55] T. Priengprom, T. Ekalaksananan, B. Kongyingyoes, S. Suebsasana, C. Aromdee, and C. Pientong, "Synergistic effects of acyclovir and 3,19- isopropylideneandrographolide on herpes simplex virus wild types and drug-resistant strains," BMC Complementary and Alternative Medicine, vol. 15, no. 1, article 56, 2015.

[56] G. Belardo, O. Cenciarelli, S. La Frazia, J. F. Rossignol, and M. G. Santoroa, "Synergistic effect of nitazoxanide with neuraminidase inhibitors against influenza A viruses in vitro," Antimicrobial Agents and Chemotherapy, vol. 59, no. 2, pp. 10611069, 2015.

[57] E. Vilanova, C. C. Coutinho, and P. A. S. Mourão, "Sulfated polysaccharides from marine sponges (Porifera): an ancestor cell-cell adhesion event based on the carbohydrate-carbohydrate interaction," Glycobiology, vol. 19, no. 8, pp. 860-867, 2009.

[58] R. Bouhlal, C. Haslin, J.-C. Chermann et al., "Antiviral activities of sulfated polysaccharides isolated from Sphaerococcus coronopifolius (Rhodophytha, Gigartinales) and Boergeseniella thuyoides (Rhodophyta, Ceramiales)," Marine Drugs, vol. 9, no. 7, pp. 1187-1209, 2011.

[59] N. N. Besednova, I. D. Makarenkova, T. N. Zvyagintseva, T. I. Imbs, L. M. Somova, and T. S. Zaporozhets, "Antiviral activity and pathogenetic targets for seaweed sulfated polysaccharides in herpesvirus infections," Biochemistry (Moscow) Supplement Series B: Biomedical Chemistry, vol. 10, no. 1, pp. 31-42, 2016.

[60] E. A. Govorkova and R. G. Webster, "Combination chemotherapy for influenza," Viruses, vol. 2, no. 8, pp. 1510-1529, 2010. 

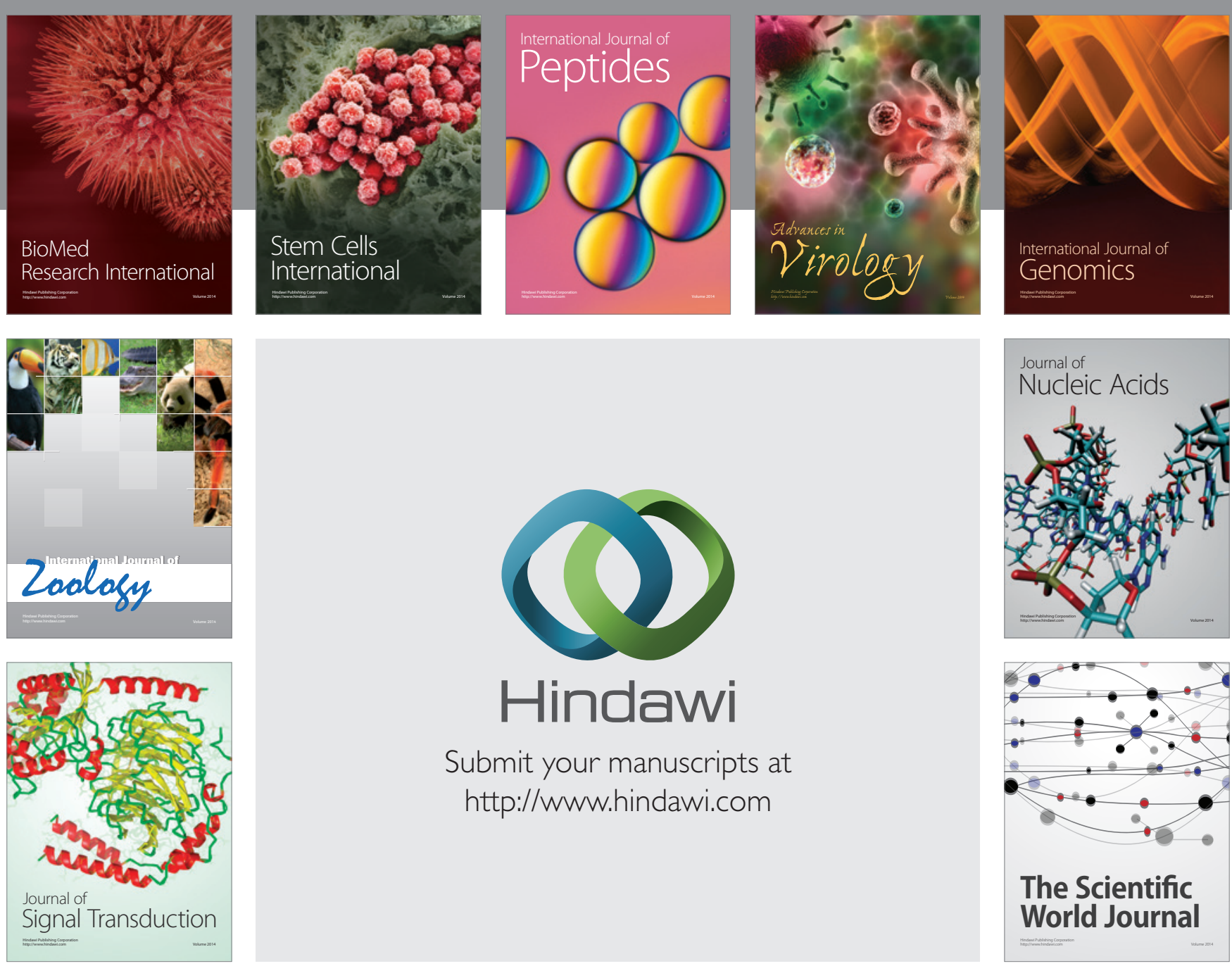

Submit your manuscripts at

http://www.hindawi.com
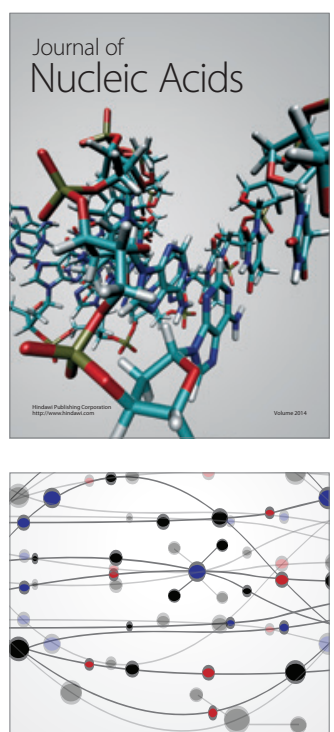

The Scientific World Journal
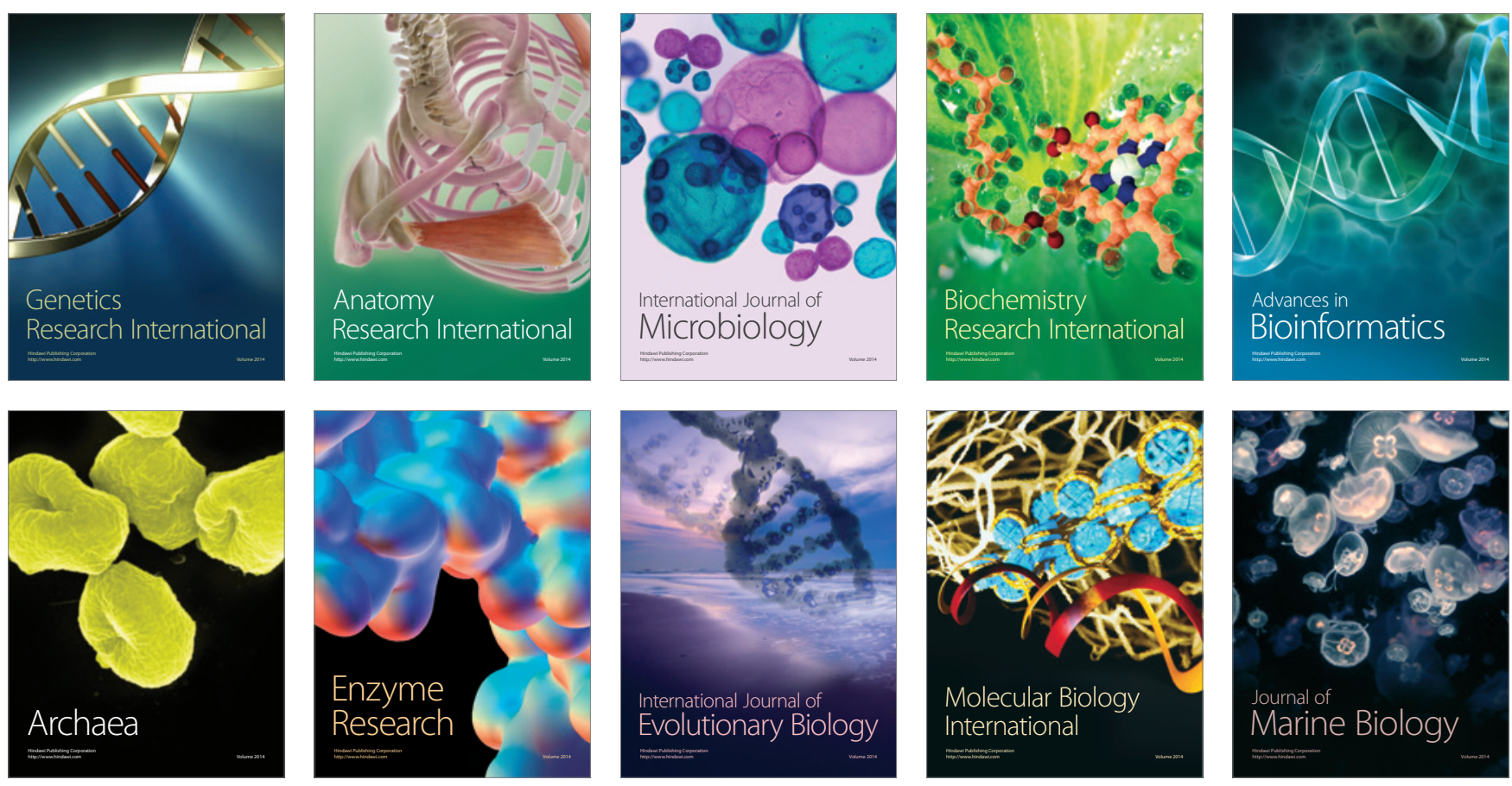